Article

\title{
Young Tourists and Sustainability. Profiles, Attitudes, and Implications for Destination Strategies
}

\section{Federica Buffa}

Department of Economics and Management, University of Trento, Via Inama 5, Trento 38122, Italy; E-Mail: federica.buffa@unitn.it; Tel.: +39-0461-282146; Fax: +39-0461-282241

Academic Editors: Gianna Moscardo and Marc A. Rosen

Received: 31 August 2015 / Accepted: 13 October 2015 / Published: 20 October 2015

\begin{abstract}
Global trends highlight the growing tourist interest in authentic and sustainable holiday experiences. Designing strategies that enable destinations to catch this tourist segment is, therefore, becoming more and more important for competitiveness. A long-term outlook calls into question the "next generation" of actual and potential tourists, i.e., young people: understanding their attitude towards sustainability is paramount to drive tourism development in a direction which is coherent to the forthcoming demand. Drawing from an ad hoc survey of 1156 members of the largest Italian association of student and youth tourism, this contribution (a) discusses youth attitudes towards sustainability, their travel motivations and behavior (b) identifies different profiles of young tourists with reference to sustainability. By using characteristics and dimensions linked with "harder ecotourists" we identify hard path young tourists (HPYT) and soft path young tourists (SPYT). The findings confirm young people's interest in certain dimensions of sustainability and the influence this interest has on their decision-making processes, motivations, and behaviors. HPYT and SPYT are profiles which should be considered in destination strategies: the strong sensitivity of HPYT to sustainability suggests the possibility of creating offers that optimize the unique features of a territory.
\end{abstract}

Keywords: sustainable tourism; destination strategy; young tourists; youth attitudes; youth behaviors; tourist profile; sustainability

\section{Introduction}

The influence of megatrends on the tourism sector highlights how important it is that destinations and enterprises understand these changes and the consequences that they can have on both tourist values and 
attitudes and on tourism forecasts [1]. The data on certain trends related to social drivers are particularly meaningful. Among them, individualism, the search for a variety of experiences, self-improvement, experimental, and increased social and environmental awareness are trends which show a growing demand for authentic holiday experiences [1]. Tourists seek involvement and interaction with local people and the opportunity to discover a destination's unique features and to acquire new knowledge. Increased authenticity [2-7] can boost tourist satisfaction and improve the tourism experience [8-12] and attract new demand segments, as has been shown in studies carried out in mature destinations [13].

From a managerial point of view, destinations evaluating their own competitiveness need to take into account the existence and effects of both megatrends and tourists' motivations and behavior. In accordance with the main principles of destination management (see the review in [14]) and with the current debate on the role of DMOs in the definition of tourist offers [15], it is clear that destinations should follow proactive strategies that create new tourist products adapted to current trends. It should, thus, be possible to overcome the limitations of the "impersonal, non-interactive system of mass tourism" [1] (p. 67). The implications of these megatrends for tourist demand also indicate the extent to which strategies for sustainability can become drivers for destination competitiveness [16-19], lending weight to the thesis of the inseparability of sustainability and competitiveness which is amply illustrated in Ritchie and Crouch [20] and subsequent studies.

Sustainable tourism and related issues are vastly debated and sometimes questioned: the actual possibility to promote sustainable local development and improve local quality of life through tourism is alternatively supported or doubted [21,22], while feasible strategies and best practices are still under discussion [22,23]. Researchers call for noteworthy efforts to promote key elements of sustainability and educate actual and future generations [24], the latter being crucial for the destination's development in the long run [25]. Understanding holiday motivations and behaviors of this segment are, therefore, key factors to design proper, effective, and long-term destination strategies.

In the light of these considerations, this paper focuses on tourist demand, identifying the travel behaviors and motivations of a specific segment: young tourists. The aim of the research is two-fold. First, to analyze the sensitivity of young tourists to sustainability. The behavior and motivations of young tourists is a topic of current interest for both international organizations and the scientific community. Young people are one of the main targets of the EU "Europe 2020 strategy", aimed at increasing their opportunities to study and/or work abroad (see the initiative Youth on the move). Internationally, young travellers' mobility is encouraged by the World Youth Student and Educational (WYSE) Travel Confederation, an affiliate of UNWTO (www.wysetc.org/unwto). Data from the UNWTO [26], the UNWTO and WYSE Travel Confederation [27], and the WYSE Travel Confederation [28,29] highlight the current and future importance of young tourists - both in quantitative terms (the size of the segment and the growth of tourist flows) and with regard to spending power. The growing importance of this market is also underlined by the strategic partnership formed in June 2014 between the UNWTO and the WYSE Travel Confederation, intended to enable collaboration on projects that will increase understanding of the youth, student, and educational travel sector. Notwithstanding the importance of this segment, in fact, a knowledge gap does exist, with regard to travel motivations and behaviors [30]. In addition, little research has been done to date into young tourists' interest in, and sensitivity to, sustainability and sustainable tourism offers [30-36].

The second aim of the research is to examine whether the young tourist segment includes profiles with different degrees of sensitivity to sustainability. Based on previous research on the links between 
sustainable tourism, tourist demand, and young tourists, our study identifies two different profiles. The characteristics and dimensions linked to "harder ecotourists" described by Weaver and Lawton [37] allow for the identification of "hard path young tourists" and "soft path young tourists" and highlight differences in their organizational, motivational, and behavioral profiles. From a strategic point of view these results allow us to reflect on the relevance of values and needs of this tourists segment for destinations in the (re)definition of tourism products.

\section{Literature Review}

\subsection{Sustainable Tourism and Tourist Demand}

Following the publication of "The Brundtland Report" [38] and the debate it ignited on the subject of sustainable development, since the late 1980s academics in the field of tourism have also been considering the necessity/opportunity of striking the right balance between the consumption of resources involved in tourism and local development within a territory [39,40]. Inskeep [41] and Swarbrooke [42] welcome such stimuli and draw attention to the links between the use of resources for tourism and the sustainability of tourist development, highlighting the need to find a balance between resource use and the three pillars of sustainability: the economic, the environmental, and the social. Starting from these considerations, many scholars have investigated the main topics of sustainable tourism, focusing on its particular characteristics, criticalities, and implications in relation to:

- the planning, governance, management, and competitiveness of tourism destinations [20,43-52].

- the analysis of the behavior and motivations of the segments of demand that are interested in sustainable tourism offers [37,53-60].

Some authors are of the opinion that the sheer quantity of research that has been done in this area has led to confusion around the terminology used in discussions of sustainable tourism $[39,61-65]$. This phenomenon is especially evident in the research on tourist demand, and particularly that into "new travellers" interested in new/alternative forms of tourism [66]. In fact, there has been considerable interest in the study of these segments, most notably in relation to ecotourism. Numerous studies have analyzed the motivational and behavioral factors involved and have identified four main segments:

- ecotourists [67-77]

- $\quad$ nature-based tourists [78-85]

- responsible tourists [86-90]

- green tourists $[91,92]$

One of the first points revealed by these researches is that there is now widespread concern about the issues of sustainability, across different segments of demand [93], and, furthermore, a growing trend in this direction $[66,77]$ which, it has been predicted, may even result in its becoming a megatrend in the tourism sector [1].

In contrast to the consensus on a growing interest in sustainable tourism, it is much more difficult to identify the actual motivations and behaviors that distinguish these segments. As has been noted in the various definitions of sustainable tourism and ecotourism (see in particular $[22,23,75,94]$ ), even analyses of segments of demand and their related characteristics are not easily made. These difficulties are increased 
by the fact that there are socio-demographic, motivational, attitudinal, and behavioral perspectives that cross segments $[71,76,77,91,95]$ making the identification of the "so-called true ecotourist", and distinguishing from other segments, difficult [96].

The general observation can be made, however, that these segments (in particular ecotourists and nature-based tourists) are older, better educated, and better off than general travellers and mass tourists $[71,72,74]$. Various studies have produced conflicting data on tourist gender: some show a prevalence of male/female tourists, in others there is no significant difference between the genders (see particularly the review in [72] (p. 260)).

Regarding motivation and behavior, on the other hand, the main similarity between the segments is tourist interest in products and holiday experiences consistent with sustainable principles. What differentiates them is their levels of sensitivity to various aspects of sustainability. In fact, although it differs in intensity, a focus on the environment and natural resources is the main characteristic shared by ecotourists, nature-based tourists, and green tourists. However, the first group also expresses particular interest in the educational and learning aspects of tourism, while the second focuses on the environment, identifying the contemplation of nature as their main motivation [95,97-100]. Lastly, green tourists are often identified as being interested in rural destinations $[91,92]$. The social dimension of sustainability, on the other hand, is more significant for responsible tourists, who are particularly sensitive to the relations between tourists and host communities and the socio-cultural impact of tourism on a destination.

Due to the difficulty of discriminating between these segments, Weaver and Lawton's reflections [75] on Laarman and Durst [101] acquire great significance. Indeed, through an understanding of the varying levels of interest in the ecotourism offer expressed by different sectors of the demand, Laarman and Durst highlight its "soft" and "hard" dimensions: segments are not only differentiated by their motivations but also by the strength of these motivations. Following this approach, other researchers have highlighted this aspect and defined "weaker (lighter green) and stronger (darker green) interpretations of sustainable tourism" [102] (p. 10); the "soft" and "hard" behavior of the ecotourist demand [68,103,104]; "hard path" and "soft path" ecotourism [105], "hard", "medium" and "soft" ecotourism [80]; rather than the "harder", "structured" and "softer" ecotourists as ideal types positioned on an ecotourism spectrum [37]. Weaver and Lawton [37] describe the behaviors, motivations, and opinions revealed in the statements of 1180 tourists at two eco-lodges in Lamington National Park (Australia). The research identifies and describes "harder" ecotourists as being strongly committed to the environment, interested in enhancing sustainability, physically active, expecting few or no services, placing emphasis on personal experience, preferring specialized trips, long trips, small groups and being willing "to donate extra money to support ecotourism sites" [37] (pp. 274, 279).

These researchers introduce elements of particular relevance to the study of tourist demand. The new tourists are distinguished by different levels of sensitivity; their behavior and motivation is not necessarily compatible with sustainable tourism. "Soft" tourists, in fact, although interested in nature and the beauty of landscapes, may require levels of service and facilities that mean they choose offers/destinations which do not necessarily focus on sustainability. As Weaver and Lawton [66] point out "soft ecotourism activity often occurs on a large scale within certain accessible protected areas, leading to the observation that ecotourism can and often does also occur as a form of mass tourism" (p. 363). Weaver [106] also points out that mass tourism does not have to be unsustainable; nevertheless it is clear that the management of "hard" or "soft" segments can require very different strategies on the part of destinations 
which do not necessarily imply the creation of sustainable tourism offers. Softer ecotourists favor multi-purpose trips, short trips, and larger groups, are moderately committed to the environment and to steady state sustainability, are physically passive, expect services to be available, and give emphasis on interpretation [37] (p. 279).

\subsection{Sustainable Tourism and Young Tourists}

The complexity of tourist behavior has been frequently stressed in numerous sociological, psychological, and managerial studies, dating back to the 1970s. A wide variety of analytical models and variables have been used (socio-economic, demographic, psychographic) to identify different tourist profiles and their particular choice mechanisms, motivations, and behaviors [107-115]. The complexity of this process is clearly revealed in the large body of work already mentioned on the analysis of sustainable tourism, in which the similarities and differences between various segments are not always easily understood.

In recent years, the scientific community has increasingly turned its attention to an examination of one particular segment of tourist demand - the young. Youth are "the new visitors in the tourism market" [35] (p. 5). "The importance of this market segment lies in the fact not only that it is becoming larger but also that it represents the market of the future" [116] (p. 1). The study of this section of the market requires, first of all, that the criteria and variables used to define an individual as a member of the "young" be identified so that their decisional processes, motivations, and behavior can subsequently be observed and described. The socio-demographic identification of this segment gives us objective information, but does not resolve the question of what age an individual ceases to be "young". As Pendergast [35] points out, generational theory, which takes into account the demographic aspects, makes an important contribution to population analysis through the identification of generations by linking each birth year to its relative age range. Such an analysis reveals that the generation which currently includes the young is Generation Y (Gen Y) - people born between 1982 and 2002. Although the actual age range and, consequently, also the socio-demographic characteristics, associated with Gen Y, are still debated [117], it is possible to connect this cohort with events (notably the birth of the new technologies and the 9/11 terrorist attacks) and with social phenomena (i.e., greater independence, better education, changing roles within the family, and changing family structures, etc.) with which particular habits and attitudes are associated (i.e., frequency of Internet use, access to social networks, concerns about security and crime, leaving home later, more working mothers). Certain inconsistencies emerge, however [30,35] (for in-depth analysis of the social characteristics and consumer patterns of Gen Y see the review in [33]; for detailed research on the online behavior of Gen Y see [34] and cited works).

Little research has been done to date on Gen Y and tourism [30], but it is a particularly interesting area of study given that Gen $\mathrm{Y}$ is "one of the largest consumer cohorts today with some of the highest levels of discretionary spend at their disposal" [33] (p. 5). Most of the data on the motivations and behaviors of the young in regard to holidays come from the studies done on a sub-cohort of Gen Y, youth, and student travellers. Chhabra [31] emphasizes the importance of understanding their consumer black box because "it is important for marketers to understand what happens inside the black box and how various stimuli are transformed into responses that reflect in the travel choices of tourists" (p. 345). The UNWTO [26] underlined the growing importance of the young tourist segment (compared to other market segments), in terms of both tourist flow and spending power. The WYSE Travel Confederation [28] underlines the fact 
that, in comparison with the past, this segment includes a wider population range: people aged 15-30+, rather than 18-24. From the behavioral point of view, it underlines the fact that youth and student travellers are keen to discover and learn about different cultures and to be able to interact with local populations. These factors open up the possibility of promoting, through this segment of tourist demand, behaviors that are more responsible and more aware of the various aspects of sustainability. Data from the UNTWO and WYSE Travel Confederation [27] supports these findings, describing youth and student travellers as "paving the way for responsible tourism". Other studies provide a detailed analysis of students" environmental attitudes and ecological beliefs, highlighting a general interest among the young in these questions (see particularly [118] and their bibliography).

The young traveller segment is also examined in studies of backpacker motivations and behaviors, but here too there are gaps in our knowledge of young peoples' sensitivity to issues of sustainability. This may be explained by the following factors:

- Demographics: many, but not all, backpackers are young. In Loker-Murphy and Pearce's [119] conceptual framework, age (along with budget and degree of organization) is one of the factors that distinguishes backpackers from other segments: the authors are referring to the youth tourist segment, but older tourists may also fall into this category. Cohen [120] makes it clear that while most backpackers are young (between 20 and 30), older backpackers certainly exist, and their motivations and journey lengths tend to differ from those of the young. Larsen, Øgaard, and Brun [121] point out that backpackers do not fall within a clearly defined age range; in support of their argument they cite the research carried out by Elsrud [122] on backpackers aged between 18 and 71.

- Territorial context: backpacking, although practiced in Europe (particularly in Scandinavia, the UK, and Germany), is much more common elsewhere (Australia, New Zealand, North America, and South East Asia in particular) [119,121,123-125].

- Motivations and behaviors: backpackers' motivations and behaviors are influenced by their socio-cultural backgrounds [126,127] which are also reflected during their holidays "in the scope of their interactions with other backpackers" [120] (p. 99). Analysis of their motivations and behaviors is often clouded by a stereotypical view of backpackers and by the motivations which originally gave rise to backpacking as a "rite of passage" between youth and adulthood [120,128], referring back to the educational meaning of travel typical of the days of the Grand Tour (for details on the origin of backpacking, see $[119,125,126])$.

Loker-Murphy and Pearce [119] define backpackers as "travellers who exhibit a preference for budget accommodation; an emphasis on meeting other people (locals and travellers); an independently organized and flexible travel schedule, longer rather than brief holidays; and an emphasis on informal and participatory recreation activities". An overall picture emerges of people who distance themselves from mass tourism, favor locally-produced goods and services [123], sporting activities and contact with nature, are interested in environmentally-oriented activities, the educational side of travelling and having authentic holiday experiences [119,129] and are less interested in luxury, comfort and relaxing [121].

Backpackers, however, are very heterogeneous: the above profile cannot be generalized to the whole segment, elements of which are strongly effected by their social and national backgrounds [127,130,131] and lifestyles [132]. Larsen et al. [121] also point out that some characteristics, a desire to discover new cultures, for example, are not peculiar to backpackers, but rather are shared by other segments of demand. 
So, we see that this strand of research investigates the motivations and behaviors which also engage the young more generally, but some specific characteristics of backpackers (including their sensitivity to certain dimensions of sustainability) [129] cannot also be attributed to the wider segment of youth and student travellers.

In the light of these observations, we consider that the investigation of young tourists' motivations for travel and behavior while travelling and of their sensitivity to sustainability, thus, appears to be an interesting area of study which could contribute, on the one hand, to increasing our knowledge of this segment and, on the other, to suggesting destinations how to improve and/or redefine their tourist offer. This seems to be particularly the case given the limited attention paid, until now, by researchers in the area of sustainable tourism to this segment of demand [32].

\section{Methodology}

\subsection{The Population}

Our field research analyses the holiday behavior and motivations of young tourists in Italy. We have enjoyed the cooperation of the Centro Turistico Studentesco e Giovanile (student and youth tourism centre) (CTS). This association, founded in 1974, is the largest Italian organization involved in the promotion, development, and organization of youth tourism. CTS sees travel as a means of spreading knowledge, preserving natural habitats and historic, artistic and cultural heritage and enriching young people's leisure time. Among its objectives are the promotion and diffusion of forms of responsible tourism coherent with the principles of sustainable development and environmental protection, and respectful of the rights of local communities (http://associazione.cts.it/).

Given the above, we began with the hypothesis that CTS tourists were an interesting subject for a case-study investigating the motivations and behaviors of young tourists interested in the aspects of sustainable tourism.

\subsection{The Questionnaire}

Our collaboration with CTS gave us access to the mailing list of its 20,140 registered users. CTS sent an email to its registered members in which it explained the research objectives and gave a link to our online questionnaire. The questionnaire contains 28 questions in four sections. These sections cover the social and personal data of tourists and go into greater detail on the following topics:

- Organizational factors: analysis of factors such as the size of the tourist group (also revealing connections with "do-it-yourself" rather than intermediated tourism), their destination, and type of accommodation. With regard to information sources (the Internet, word of mouth, tourist guides, documentaries and TV programs, specialized magazines/journals, travel agents, tour operators' catalogues, radio, advertising), particular attention is paid to how regularly specialized magazines, dealing with issues such as environment, ecology, culture, and social responsibility, are read.

- Factors influencing the decision-making process: analysis of how the environmental, economic, and social factors influenced choices of destination, accommodation, and tour operator. With regard to destinations, particular attention is paid to the analysis of how important tourists felt the discovery of new cultures and landscapes, the contemplation of a destination's artistic and natural heritage, 
and contact with nature and local community to be. Regarding choice of accommodation, our research reveals the importance of the outcome of tourism for the local community, through the use of local products and local staff. Lastly, in the choice of tour operator, we focus on the importance attributed to the ethical aspects of the journey and the company, and the extent to which tour operators supported a destination's development projects and environmental protection strategies and hired local guides. Our analysis of these factors used reply options which required respondents to give a score to each item, grading their attribution of importance on a four point scale (to avoid respondent's fatigue on a longer scale but at the same time have them take a position) from "very important" to "not at all important".

- Behavioral factors: analysis of statements about behaviors adopted during the holiday and factors which may have influenced the purchase of locally-produced products. Particular attention is paid to respondents' willingness to integrate with the local community and to be involved in events organized by it and to commitments to learning about the local environment, culture, and history in order to minimize the negative impact of tourism upon the host community. For the analysis of behaviors, we also asked definite questions, using a projective technique (the third-person technique) in order to reveal less biased opinions than those stated by the respondents. Projective techniques were introduced in psychology but are regularly deployed also in marketing research. One of the most common is the "third-person test". In this technique the respondent is required to describe how s/he would tackle a task or a situation by identifying him/herself in a hypothetical subject, i.e., a third person. This allows researchers to address potentially sensitive issues, and enable the respondent to analyze situations from a certain distance, thus expressing his/her opinions/evaluations on specific topics more objectively (for further information see [133]). The questionnaire developed for this research included the question "How much does Daisy look like you?" with reference to issues related to sustainable tourism behavior. Possible answers ranged from "a lot" to "not at all".

Our research also investigated people's willingness to pay a premium (on the next holiday) in order to protect the local environment, support the culture and the local community, limit the negative impact of tourism, and guarantee decent wages and good working conditions to local workers. The willingness to pay was evaluated by giving four reply options: paying a premium "of more than $20 \%$ ", "between $10 \%-20 \%$ ", "less than $10 \%$ " or "no premium at all".

\subsection{Statistics and Data Analysis}

The research is based on 2020 online replies to our questionnaire. Most respondents $(57.2 \%)$ were between 19 and 29 years old, 25.9\% were between 30 and 39, 9.4\% between 40 and 49 , and $7.5 \%$ were over 50. As the focus of research was young tourists, and in the light of the points highlighted in the literature review regarding socio-demographic characteristics, the decision making-process, motivations and behaviors of the 1156 respondents aged between 19 and 29 were analyzed. Although the exploratory nature of the research does not permit us to extend the results to the entire population observed, we consider that the high number of questionnaire responses, consistent with other international research (see [37]) makes it possible to identify characteristics which contribute to the analysis of the young tourist profile.

The elaboration of the data involves two steps. The first uses descriptive statistical tools and analyses aggregate data on young tourists to map their main organizational, motivational, and behavioral 
characteristics and their sensitivity to sustainability (see Section 4.1). This step allows us to achieve the first research goal.

The second step identifies "hard path young tourists" (HPYT) and "soft path young tourists" (SPYT), measures the composition of the two profiles and analyses the personal, organizational, motivational, and behavioral characteristics of the two groups. The identification of HPYT uses variables associated with harder ecotourists [37]. The results of this analysis are described in the Section 4.2. The analysis and comparison of the HPYT and the SPYT profiles use descriptive statistical tools and are supported by the results from non-parametric tests (two proportions test). The two proportions measured are HPYT and SPYT. The comparisons of these two proportions is performed with $\alpha=0.01$ and $\alpha=0.05$. This second step of the analysis allows us to describe the organizational, motivational, and behavioral profiles of HPYT and SPYT (see Section 4.3), thus fulfilling the second aim of the research.

\section{Results and Discussion}

\subsection{Young Tourists and Sensitivity to Sustainability}

The young tourists are mainly students (with a university degree or a high school diploma), women, living in Northern Italy, unmarried, with no children (Table 1). The main characteristics linked to the organizational profile of the respondents are: over $70 \%$ prefer to organize their holidays independently; about $44 \%$ state that they never travel with organized groups and $51 \%$ prefer small groups (less than 10 people). The Internet is the main information source (94.3\%), followed by word-of-mouth ( $81.9 \%)$ and the consultation of tourist guides (72.8\%). About 58\% are interested in reading supplements of magazines devoted to environmental, ecological, and cultural matters. Italy (85.3\%) and other European countries $(77.7 \%)$ are the most visited destinations. Hotels are the most frequently used accommodation (75.2\%).

Table 1. Socio-demographic variables of young respondents (age: 19-29 years) (note: data expressed in the form of percentages).

\begin{tabular}{ll}
\hline Socio-Demographic Variables & Main Results $(\boldsymbol{n}=\mathbf{1 1 5 6})$ \\
\hline Gender & women $(73.0)$-men (27.0) \\
Place of residence & northern Italy (50.6)-central Italy (30.6)-southern Italy (18.8) \\
Marital status & single (94.4)-married/cohabiting (5.6) \\
Family unit & no children (92.9)-independent children (5.4)-small children (1.6) \\
Job & student (55.6)-employee (23.7)-self-employed (8.9)-unemployed (4.8)-others (6.9) \\
Education & university degree (53.8)-high school diploma (44.7) \\
\hline
\end{tabular}

The findings confirm young people's interest in certain dimensions of sustainability and the influence this interest has on their decision-making process, motivations and behaviors (see Table 2). 
Table 2. Dimensions of sustainability influencing the decision-making process of young tourists in the choice of the destination, accommodation, and tour operator ( $n=1156)$ (note: data expressed in the form of percentages).

\begin{tabular}{lcccc}
\hline & $\begin{array}{c}\text { Very } \\
\text { Important }\end{array}$ & $\begin{array}{c}\text { Quite } \\
\text { Important }\end{array}$ & $\begin{array}{c}\text { Not Very } \\
\text { Important }\end{array}$ & $\begin{array}{c}\text { Not Important } \\
\text { at All }\end{array}$ \\
\hline CHOICE OF DESTINATION & & & & \\
discovery of new cultures & 75.2 & 21.9 & 2.3 & 0.6 \\
discovery of new landscapes & 71.5 & 26.2 & 2.0 & 0.3 \\
contemplation of natural/artistic heritage & 66.1 & 28.3 & 4.8 & 0.9 \\
contact with the local community & 47.1 & 38.3 & 13.1 & 1.5 \\
contact with nature & 43.9 & 40.8 & 13.4 & 1.9 \\
CHOICE OF ACCOMMODATION & & & & \\
profits benefiting the local community & 14.0 & 31.4 & 36.0 & 18.6 \\
CHOICE OF TOUR OPERATOR & & & & 3.5 \\
ethicality of the journey and of the organization & 41.3 & 43.1 & 12.1 & 24.7 \\
support for local development projects and environmental protection & 28.0 & 40.9 & 2.9 & 6.4 \\
involvement of local guides & 23.2 & 41.6 & 27.8 & 7.4 \\
\hline
\end{tabular}

With regard to the decision-making process we see that:

- in the choice of destination the motivations considered most important are the discovery of new cultures, discovery of new landscapes, contemplation of natural and artistic heritage, contact with local community, contact with nature;

- in the choice of accommodation price is the most influential factor (over $65 \%$ consider it very important and more than 30\% quite important); factors more relevant to sustainability, like the actual return and benefit to the local community from tourism, are considered of little importance by the majority of respondents;

- in the choice of a tour operator price is the most influential factor (over 67\% consider it very important); the ethicality of the journey and the organization are also very important; most respondents consider support for local development projects and environmental protection and the involvement of local guides, to be quite important.

Their statements about behavior show that about $40 \%$ of respondents are willing to pay a premium of up to $10 \%$ on their next holiday in order to support local cultures and communities, protect the environment, limit the negative effects of tourism, and ensure that local workers have good wages and working conditions.

Most young tourists say they prefer local food, adapt as much as they can to the traditions and customs of the place in which they are holidaying, try to learn about their destination before travelling, would be willing to be involved in events organized by the local community and to interact with it, demonstrate interest in the protection of the authenticity of the destination, even if this means going without certain comforts, find out how to protect the local environment and reduce waste, and are concerned to ensure that their spending benefits the local population. 


\subsection{Identification of Hard Path Young Tourists (HPYT) and Soft Path Young Tourists (SPYT)}

Acknowledging the general interest of young tourists in sustainability, this research examines in detail the characteristics of those young people who express interest in all the dimensions of sustainability covered in this research, identifying hard path young tourists (HPYT) and soft path young tourists (SPYT) and analyzing their personal, organizational, motivational, and behavioral characteristics. To this end, variables and criteria, by which each interviewee is associated with one profile or the other, have been defined.

The choice of variables is based on the main characteristics to emerge from the literature of the "hard" profile, referring in particular to those linked with harder ecotourism described by Weaver and Lawton [37]: small groups, enhancing sustainability, strong environmental commitment, and emphasis on personal experience. These characteristics are traced back to motivational and behavioral variables which illustrate an interest in sustainability (environmental, economic, and social). For example, the willingness to pay a premium in order to protect the local environment and limit the negative impact of tourism is a variable which illustrates a behavior linked to the characteristics of strong environmental commitment and a desire to enhance sustainability (environmental and social dimensions) as described by Weaver and Lawton [37].

With regard to the exploratory nature of the research, particularly restrictive criteria have been adopted in the association of each respondent to the HPYT profile. This allows us to clearly identify the two profiles and to record their organizational, motivational, and behavioral characteristics which will be more closely investigated through further research.

The variables and criteria used to identify the HPYT profile are shown in Table 3. This profile exhibits a high level of sensitivity to all the observed dimensions: it includes 198 respondents; that is about 17\% of the young tourists. The other respondents that do not satisfy all the criteria are classified as SPYT.

An analysis and comparison of the personal, organizational, motivational, and behavioral characteristics of HPYT and SPYT follow below. Unless otherwise indicated, the results of the tests refer to values of $\alpha$ to 0.01 .

\subsection{Hard Path Young Tourists vs. Soft Path Young Tourists}

\subsubsection{Personal Profile}

The comparison between gender, family composition, and professions of HPYT and SPYT confirms, as described for the whole sample, the prevalence of women, family without children, students (over 50\%) and employees (about 24\%).

Statistically significant differences emerge in marital status, education, and participation in groups or associations. Although the majority of respondents in both profiles are single, this is more significant among the SPYT; most of the young have degrees or qualifications, but graduates are more prevalent among the HTPT; there are more students with high school diplomas in the SPYT profile $(\alpha=0.05)$. Although membership of groups and associations is not very widespread, the findings show that more HPYT participate in cultural and voluntary work; fewer than $20 \%$ of the HPYT are involved in environmental and political associations, but this still differentiates them from the SPYT $(\alpha=0.05)$. About a third of respondents in both profiles are members of sports associations. 
Table 3. Aspects, questions, variables, and criteria used to identify the profile of hard path young tourists (HPYT).

\begin{tabular}{|c|c|c|c|c|}
\hline Aspects & Questions & Variables & Criterion & Harder Ecotourists [37] \\
\hline $\begin{array}{l}\text { Organization of } \\
\text { holiday }\end{array}$ & $\begin{array}{l}\text { Composition of } \\
\text { the tourist group }\end{array}$ & Composition of the tourist group & $\begin{array}{l}\text { Never travel with organized groups or small groups } \\
(<10 \text { people })\end{array}$ & Small groups \\
\hline \multirow{9}{*}{$\begin{array}{l}\text { Decision-making } \\
\text { process and } \\
\text { motivations }\end{array}$} & \multirow{5}{*}{ Choice of destination } & Discovery of new cultures & \multirow{5}{*}{$\begin{array}{l}\text { All variables evaluated as "very important" or "quite } \\
\text { important" }\end{array}$} & Emphasis on personal experience \\
\hline & & Discovery of landscapes & & $\begin{array}{l}\text { Strong environmental commitment } \\
\text { Emphasis on personal experience }\end{array}$ \\
\hline & & Contemplation of natural/artistic heritage & & $\begin{array}{l}\text { Strong environmental commitment } \\
\text { Emphasis on personal experience }\end{array}$ \\
\hline & & Contact with the local community & & Emphasis on personal experience \\
\hline & & Contact with nature & & $\begin{array}{l}\text { Strong environmental commitment } \\
\text { Emphasis on personal experience }\end{array}$ \\
\hline & Choice of accommodation & Benefits accruing to the local community from tourism & Variable evaluated as "very important" or "quite important" & Enhancing sustainability \\
\hline & \multirow{3}{*}{ Choice of tour operator } & Ethicality of the journey and the tour operator & \multirow{3}{*}{$\begin{array}{l}\text { All variables evaluated as "very important" or } \\
\text { "quite important" }\end{array}$} & Enhancing sustainability \\
\hline & & $\begin{array}{l}\text { Tour operator's declared support for development projects and environmental } \\
\text { protection in the local area }\end{array}$ & & Enhancing sustainability \\
\hline & & Involvement of local guides & & Enhancing sustainability \\
\hline \multirow{12}{*}{ Behavior } & \multirow{3}{*}{$\begin{array}{l}\text { Willingness to } \\
\text { pay a premium } \\
\text { (for next holiday) }\end{array}$} & To support the culture and the local community & \multirow{3}{*}{ Declaration of willingness to pay a premium } & Enhancing sustainability \\
\hline & & To preserve the local environment and limit the negative impact of tourism & & $\begin{array}{l}\text { Enhancing sustainability } \\
\text { Strong environmental commitment }\end{array}$ \\
\hline & & To guarantee decent wages to local workers and good working conditions & & Enhancing sustainability \\
\hline & \multirow{9}{*}{$\begin{array}{l}\text { Importance or accordance } \\
\text { declared in relation to } \\
\text { specific statements }\end{array}$} & Preference for local food & \multirow{9}{*}{ All variables evaluated as "very" or "quite" } & Emphasis on personal experience \\
\hline & & Adaptation to local habits & & Emphasis on personal experience \\
\hline & & Willingness to be involved in events organized by local communities & & Emphasis on personal experience \\
\hline & & Commitment to learn about the local environment, culture and history & & Emphasis on personal experience \\
\hline & & Protection of the authenticity of the destination & & $\begin{array}{l}\text { Strong environmental commitment } \\
\text { Enhancing sustainability }\end{array}$ \\
\hline & & Interaction with local community & & Emphasis on personal experience \\
\hline & & Commitment to reduce waste and limit the impact of tourism on the local community & & Enhancing sustainability \\
\hline & & Spending benefits local population & & Enhancing sustainability \\
\hline & & Tourism effects on local community & & Enhancing sustainability \\
\hline
\end{tabular}




\subsubsection{Organizational Profile}

The organizational profiles of HPYT and SPYT differ in relation to four specific factors: composition of tourist groups, information sources used, destination, types of accommodation.

Most respondents organize their holidays independently (HPYT 86.9\% vs. 67.2\% SPYT), but this is more prevalent in the HPYT profile; SPYT are more likely to look for travel agents. Tourist groups in both profiles are usually composed of friends and relatives, but almost half the HPYT say they also travel alone. In sharp contrast, fewer than $30 \%$ of the SPYT would travel alone.

Both profiles use the Internet and word of mouth as their main sources of information. HPYT use the Internet more and are also more willing to spend time collecting information, are more autonomous in seeking this information and use multiple sources ranging from tourist guides and television documentaries to specialized journals and radio programs. SPYT, on the other hand, tend to rely on travel agencies and tour operators for information.

The HPYT profile is characterized by more regular reading of magazines dedicated to environmental, ecological, geographical and cultural topics, civil society, social responsibility, and critical consumption.

Italy and Europe are the favorite destinations for both profiles, but about 15\% of the HPYT had visited North or South America in the previous year $(\alpha=0.05)$.

Friends' or relatives' houses and hotels are young tourists' preferred accommodation. HPYTs, however, are more likely than SPYTs to choose private homes $(67.2 \%$ vs. $57.8 \%$ SPYT; $\alpha=0.05)$ and vice versa for hotels (77.2\% SPYT vs. 65.2\% HPYT). Campsites and agritourisms are also more popular among HPYT, residences and tourist villages are more often the choice of SPYT (in both cases results with $\alpha=0.05$ ).

\subsubsection{Motivational Profile}

The following motivations influence HPYTs' and SPYTs' choice of destination, accommodation and, if relevant, tour operator:

- Destination choice: adventure is the most important factor for most HPYT; relaxing and/or entertainment and a search for comfort are more typical of the SPYT. Both profiles attribute little importance to sport.

- Accommodation choice: price is the most important variable for both profiles. It is, however, consistent with the HPYT profile that motivations linked to availability of local produce and locally-employed staff follow that of price for HPYT, unlike SPYT who value comfort more highly.

- Choice of tour operator: the motivations of both profiles are equally influenced by price, followed by the quality standards of the organization.

\subsubsection{Behavioral Profile}

Over $90 \%$ of HPYT and SPYT have been to restaurants, pubs or local lodgings. Both profiles are interested in visiting museums or places linked to local folklore and traditions, and buying local and DOC products, but this is more markedly the case for HPYT.

Buying fairly-traded and organic products is clearly more important to HPYT, most of whom would be willing to pay premiums of as much as $20 \%$. Most SPYT would be willing to accept premiums up to 
$10 \%$ or more, while one in six tourists is not willing to accept increased prices; which differentiates them from the HPYT.

The SPYT differ from the HPYT in that they are willing to pay a premium $(10 \%-20 \%)$ to ensure that their holiday will go according to plan, and to increase the comfort and the quality of their holiday.

HPYT and SPYT differ in their descriptions of their behavior while on holiday. For HPYT the importance of protected areas, typical local products, and organic products is greater; they also worry more about pollution, are more aware of the impacts of tourism on the climate and the environment, more willing to forgo skiing if the only available snow is artificial. Moreover, they judge many tourists not to be sufficiently respectful of the environment or local customs.

\section{Discussion and Implications}

The study analyzed a select population of young tourists (members of CTS) and focuses on their personal, organizational, motivational, and behavioral characteristics. The first step of the analysis confirms some of the trends highlighted in the UNWTO report [26] and UNWTO and WYSE Travel Confederation [27] regarding youth and student travellers' interest in several dimensions of sustainability. An interest in environmental attitudes and ecological belief as highlighted in Benckendorff et al. [118] is also confirmed, as is the importance for the young of the Internet as a source of information.

Of course, young tourists vary in the intensity of their interest in sustainability. The adoption of very strict criteria for segmentation has allowed us to identify and distinguish HPYT and SPYT and analyze their decision-making processes, motivations, and behaviors. The greater independence and autonomy shown by HPYTs in the organization of their holidays and their willingness to pay premiums find confirmation in the harder ecotourist profile described by Weaver and Lawton [37]. In contrast, the SPYT tendency to rely on agencies to make their travel arrangements, the importance they place on comfort and relaxation, and their willingness to spend more in order to ensure they can relax in comfort, correlates the SPYT profile with that of Weaver and Lawton's softer ecotourists.

The analysis of HPYT and SPYT reveals two profiles which could be considered by destinations in the planning on their strategic and operational choices. Examples of this might be the means of communication (supported by travel agencies or tour operator in the case of SPYT; specialized journals for HPYT vs. general publications for SPYT) and the promotion of offers in various accommodation facilities (campsites and agritourisms for HPYT $v s$. tourist villages and residences for SPYT) or the development of particular local attractions and products. Both profiles are interested in local products, but HPYT are more willing to accept limits to their consumption and are more aware of the impact of tourism on places and communities. In addition, the strong sensitivity of HPYT to sustainable offers suggests that destinations could create tourist offers that optimize the unique features of the territory. The optimization of a territory's distinctive features (natural resources, historical, artistic, and cultural heritage) alongside the limiting of access and resource use can allow destinations to develop new products and to differentiate the offer in order to better respond to the specific needs of the young profiles, and at the same time preserve the natural, economic, and socio-cultural capital of the territory and increase the authenticity of the tourism experience $[3,9,12]$.

Our research has drawn attention to the motivations and behaviors of a share of tourist demand which shows a steady interest in sustainable tourism and analyzes a subject on which little work has yet been done. The exploratory nature of the research does not allow us to extend the results to the whole population 
of young tourists and therefore further investigation is required. The intention is to follow two analytical paths. The first provides for the extension of this analysis to other populations potentially interested in sustainable tourism offers (i.e., members of the WWF or other environmental associations). The second examines sensitivity to sustainability by investigating the motivations and behaviors of generic populations of young tourists (such as university students).

The analysis and comparison of the results from these two research paths allows us:

- To verify the significance of the profiles which we have established and to compare the composition (weight) of HPYT and SPYT. Our research identifies about $17 \%$ of respondents as HPYT. This figure is lower than the cluster of harder ecotourists picked out by Weaver and Lawton [37], but the differences between the contexts and research methods prevent any direct comparison between the two profiles. We believe it necessary, however, to examine this issue, using the research methodology which we have adopted (variables and analytical criteria) to analyze populations of young tourists with similar/different characteristics to those of the young CTS travellers.

- To examine the relationship between young tourists and the price variable. The research reveals the strong influence this variable has on choices of accommodation and, when relevant, tour operator. Given the relatively high spending power of this tourist segment (as shown in international report and in the literature) (see [26,33]) it is worth examining this result more closely, both with regard to young tourists in general and to HPYT and SPYT.

We intend to conduct the next stages of the research using methods which integrate (a) online surveys of wide cross-sections of young tourists; (b) laboratory tests based on the methods of experimental economics; and (c) choice experiments on willingness to pay. The methodology thus adopted (bringing together research tools and techniques which have already been used by the author's research group) will allow us to verify the validity and wider applicability of the data collected in the course of this project, overcoming the limits inherent in an analysis of motivations and behavior based on personal statements.

\section{Acknowledgments}

The author wish to thank the Italian Student and Youth Tourism Centre (CTS) for collaboration. The author is grateful to prof. Mariangela Franch and prof. Umberto Martini of the Department of Economics and Management (University of Trento, Italy) for their comments and suggestions.

\section{Conflicts of Interest}

The author declares no conflict of interest.

\section{References}

1. Dwyer, L.; Edwards, D.; Mistilis, N.; Roman, C.; Scott, N. Destination and enterprise management for a tourism future. Tour. Manag. 2009, 30, 63-74.

2. Chhabra, D. Understanding authenticity and its determinants. J. Travel Res. 2005, 44, 64-73.

3. Cohen, E. Authenticity and commoditization in tourism. Ann. Tour. Res. 1988, 15, 371-386.

4. Ferrari, S.; Adamo, G.E. Autenticità e risorse locali come attrattive turistiche. Sinergie 2005, 66, 80-112. (In Italian). 
5. Hughes, G. Authenticity in tourism. Ann. Tour. Res. 1995, 22, 781-803.

6. Yeoman, I.; Brass, D.; McMahon-Beattie, U. Current issue in tourism. Tour. Manag. 2007, 28, $1128-1138$.

7. Taylor, J.P. Authenticity and Sincerity in Tourism. Ann. Tour. Res. 2001, 28, 7-26.

8. Coghlan, A. Linking natural resource management to tourist satisfaction. J. Sustain. Tour. 2012, 20, 41-58.

9. McIntosh, A.J.; Prentice, R.C. Affirming authenticity-Consuming cultural heritage. Ann. Tour. Res. 1999, 26, 589-612.

10. Noy, C. This trip really changed me. Ann. Tour. Res. 2004, 31, 78-102.

11. Walker, K.; Moscardo, G. Encouraging sustainability beyond the tourist experience. J. Sustain. Tour. 2014, 22, 1175-1196.

12. Wang, N. Rethinking Authenticity in Tourism Experience. Ann. Tour. Res. 1999, 26, 349-370.

13. Sedmak, G.; Mihalič, T. Authenticity in mature seaside resorts. Ann. Tour. Res. 2008, 35, 1007-1031.

14. Pearce, D.G.; Schänzel, H.A. Destination management: The tourists' perspective. J. Destin. Mark. Manag. 2013, 2, 137-145.

15. Beritelli, P.; Laesser, C. Getting the cash-cow directors on board-An alternative view on financing DMOs. J. Destin. Mark. Manag. 2014, 2, 213-220.

16. Chen, C.-M.; Chen, S.H.; Lee, H.T. The destination competitiveness of Kinmen's tourism industry. J. Sustain. Tour. 2011, 19, 247-264.

17. Franch, M.; Martini, U. (Eds.) Management per la Sostenibilità dello Sviluppo Turistico e la Competitività Delle Destinazioni; Il Mulino: Bologna, Italy, 2013. (In Italian)

18. Ritchie, J.R.B.; Crouch, G.I. The Competitive Destination; CABI: Wallingford, UK, 2003.

19. Weaver, D.B. Organic, incremental and induced paths to sustainable mass tourism convergence. Tour. Manag. 2012, 33, 1030-1037.

20. Ritchie, J.R.B.; Crouch, G.I. Editorial-The Competitive Destination. Tour. Manag. 2000, 21, 1-7.

21. Moscardo, G.; Murphy, L. There is No Such Thing as Sustainable Tourism: Re-Conceptualizing Tourism as a Tool for Sustainability. Sustainability 2014, 6, 2538-2561.

22. Jamal, T.; Camargo, B.A.; Wilson, E. Critical Omissions and New Directions for Sustainable Tourism: A Situated Macro-Micro Approach. Sustainability 2013, 5, 4594-4613.

23. Aall, C. Sustainable Tourism in Practice: Promoting or Perverting the Quest for a Sustainable Development? Sustainability 2014, 6, 2562-2583.

24. Bowser, G.; Gretzel, U.; Davis, E.; Brown, M. Educating the Future of Sustainability. Sustainability 2014, 6, 692-701.

25. Benckendorff, P.; Moscardo, G.; Pendergast, D. (Eds.) Tourism and Generation Y; CABI: Wallingford, UK, 2010.

26. UNWTO. Youth Travel Matters; Unwto: Madrid, Spain, 2008.

27. UNWTO \& WYSE Travel Confederation. The Power of Youth Travel. 2011. Available online: http://www2.unwto.org/publication/am-reports-volume-2-power-youth-travel (accessed on 20 August 2015).

28. WYSE Travel Confederation. Youth and Student Travel Market-Data, Statistics and Trends. 2012. Available online: http://staywyse.org/research-2/industry-review-no-1/ (accessed on 30 August 2015). 
29. WYSE Travel Confederation. Youth and Student Travel Market - Global Data, Statistics and Trends II. 2014. Available online: https://www.wysetc.org/wp-content/uploads/2015/01/IndustryReview-No.-5-Executive-Summary.pdf (accessed on 31 August 2015).

30. Moscardo, G.; Benckendorff, P. Mythbusting: Generation Y and travel. In Tourism and Generation Y; Benckendorff, P., Moscardo, G., Pendergast, D., Eds.; CAB International: Wallingford, UK, 2010; pp. 16-26.

31. Chhabra, D. What do student travelers really want? Revisiting the Buyer's Black Box. J. Hosp. Mark. Manag. 2011, 21, 344-355.

32. Cini, F.; Leone, L.; Passafaro, P. Promoting Ecotourism among Young People. Environ. Behav. 2012, 44, 87-106.

33. Leask, A.; Fyall, A.; Barron, P. Generation Y: Opportunity or challenge. Curr. Issues Tour. 2011, doi:10.1080/13683500.2011.642856.

34. Nusair, K.K.; Parsa, H.G.; Cobanoglu, C. Building a model of commitment for Generation Y. Tour. Manag. 2011, 32, 833-843.

35. Pendergast, D. Getting to Know the Y Generation. In Tourism and Generation Y; Benckendorff, P., Moscardo, G., Pendergast, D., Eds.; CAB International: Wallingford, UK, 2010; pp. 1-15.

36. Scarpato, D.; Annunziata, A.; Ardeleanu, M.P. Sustainable tourism and the perception of the young generation: An analysis of the South of Italy. Qual. Access Success 2014, 15, 254-259.

37. Weaver, D.B.; Lawton, L.J. Overnight ecotourism market segmentation in the Gold Coast hinterland of Australia. J. Travel Res. 2002, 40, 270-280.

38. WCED. Our Common Future; Oxford University Press: Oxford, UK, 1987.

39. Butler, R.W. Sustainable Tourism: A state-of-the-art review. Tour. Geogr. 1999, 1, 7-25.

40. McKercher, B. Some fundamental truths about tourism. J. Sustain. Tour. 1993, 1, 6-16.

41. Inskeep, E. Tourism Planning; Van Nostrand Reinhold: New York, NY, USA, 1997.

42. Swarbrooke, J. Sustainable Tourism Management; CABI: Wallingford, UK, 1999.

43. Bahaire, T.; Elliott-White, M. Community Participation in Tourism Planning and Development in the Historic City of York, England. Curr. Issues Tour. 1999, 2, 243-276.

44. Bramwell, B. Governance, the state and sustainable tourism. J. Sustain. Tour. 2011, 19, 459-477.

45. Bramwell, B.; Lane, B. Sustainable tourism and the evolving roles of government planning. J. Sustain. Tour. 2010, 18, 1-5.

46. Jamal, T.; Getz, D. Collaboration theory and community tourism planning. Ann. Tour. Res. 1995, 22, 186-204.

47. Nelson, J.G.; Butler, R.W.; Wall, G. (Eds.) Tourism and Sustainable Development; University of Waterloo: Waterloo, ON, Canada, 1993.

48. Plummer, R.; Fennell, D.A. Managing protected areas for sustainable tourism. J. Sustain. Tour. 2009, 17, 149-168.

49. Robinson, M. Collaboration and cultural consent. J. Sustain. Tour. 1999, 7, 379-397.

50. Selin, S. Developing a typology of sustainable tourism partnerships. J. Sustain. Tour. 1999, 7, 260-273.

51. Spenceley, A.; Meyer, D. Tourism and poverty reduction. J. Sustain. Tour. 2012, 20, 297-317.

52. Tosun, C. Roots of unsustainable tourism development at the local level. Tour. Manag. 1998, 19, 595-610. 
53. Dolnicar, S. Insights into sustainable tourists in Austria. J. Sustain. Tour. 2004, 12, 209-218.

54. Dolnicar, S. Identifying tourists with smaller environmental footprints. J. Sustain. Tour. 2010, 18, 717-734.

55. Fiorello, A.; Bo, D. Community-based ecotourism to meet the new tourist's expectations. J. Hosp. Mark. Manag. 2012, 21, 758-778.

56. González, R.; Otero, A. Alternative tourism activities management in the Argentinean-Chilean Great Lakes Corridor. Curr. Issues Tour. 2002, 5, 193-207.

57. Hunter, C. Sustainable tourism as an adaptive paradigm. Ann. Tour. Res. 1997, 24, 850-867.

58. Kline, J.D. Tourism and Natural Resource Management: A General Overview of Research and Issues. 2001. Available online: http://www.fsl.orst.edu/lulcd/Publicationsalpha_files/Kline_2001_ GTR506.pdf (accessed on 15 October 2015).

59. Middleton, V.T.C.; Hawkins, R. Sustainable Tourism; Butterworth-Heinemann: Oxford, UK, 1998.

60. Zografos, C.; Allcroft, D. The environmental values of potential ecotourists. J. Sustain. Tour. 2007, 15, 44-66.

61. Brown, F. Alternative tourism Insights, Magazine of the English Tourist Board/British Tourist Authority, 1991.

62. Clarke, J. A Framework of Approaches to Sustainable Tourism. J. Sustain. Tour. 1997, 5, 224-233.

63. Liu, Z. Sustainable tourism development. J. Sustain. Tour. 2003, 11, 459-475.

64. Harris, R.; Leiper, N.; (Eds.) Sustainable Tourism; Butterworth-Heinemann: Oxford, UK, 1995.

65. Page, S.J.; Dowling, R.K. Ecotourism; Prentice Hall: Harlow, UK, 2002.

66. Weaver, D.B.; Lawton, L.J. Tourism Management; Wiley: Milton, Australia, 2002.

67. Ballantine, J.K.; Eagles, P.F. Defining Canadian ecotourists. J. Sustain. Tour. 1994, 2, $210-214$.

68. Blamey, R.; Braithwaite, V. A social values segmentation of the potential ecotourism market. J. Sustain. Tour. 1997, 5, 29-45.

69. Buckley, R. Case Studies in Ecotourism; CABI: Wallingford, UK, 2003.

70. Fennel, D.A. Ecotourism Programme Planning; CABI: Wallingford, UK, 2002.

71. Kerstetter, D.L.; Hou, J.S.; Lin, C.H. Profiling Taiwanese ecotourists using a behavioral approach. Tour. Manag. 2004, 25, 491-498.

72. Juric, B.; Cornwell, T.B.; Mather, D. Exploring the usefulness of an ecotourism interest. J. Travel Res. 2002, 40, 259-269.

73. Lawton, L. A Profile of Older Adult Ecotourists in Australia. J. Hosp. Mark. Manag. 2002, 9, 113-132.

74. Meric, H.C.; Hunt, J. Ecotourist motivational and demographic characteristics. J. Travel Res. 1998, $36,57-61$.

75. Weaver, D.B.; Lawton, L.J. Twenty years on: The state of contemporary ecotourism research. Tour. Manag. 2007, 28, 1168-1179.

76. Wight, P. North American ecotourism markets. J. Travel Res. 1996, 34, 3-10.

77. Wurzinger, S.; Johansson, M. Environmental Concern and Knowledge of Ecotourism among Three Groups of Swedish Tourists. J. Travel Res. 2006, 45, 217-226.

78. Buckley, R.; Pickering, C.; Weaver, D.B. Nature-Based Tourism, Environment and Land Management; CABI: Wallingford, UK, 2003. 
79. Dolnicar, S.; Leisch, F. Selective marketing for environmentally sustainable tourism. Tour. Manag. 2008, 29, 672-680.

80. Hassan, S.; Mohd, A.; Mariapan, M.; Husin, M.Z. Segmentation of nature tourists through motivation of travel to Kuala Gandah national elephant conservation centre. Malays. Forest. 2010, 73, 7-15.

81. Hvengaard, G.T.; Dearden, P. Ecotourism versus tourism in a Thai national park. Ann. Tour. Res. 1998, 25, 700-720.

82. Luzar, E.J.; Diagne, A.; Ecgan, C.; Henning, B.R. Profiling the Nature-based Tourist. J. Trav. Res. 1998, 37, 48-55.

83. Mehmetoglu, M. Segmenting the Nature-Based Tourists Based on Travel Mode Choice. J. Hosp. Leis. Mark. 2006, 14, 47-67.

84. Priskin, J. Assessment of natural resources for nature-based tourism. Tour. Manag. 2001, 22, 637-648.

85. Rinne, P.; Saastamoinen, O. Local Economic Role of Nature-based Tourism in Kuhmo Municipality, Eastern Finland. Scand. J. Hosp. Tour. 2005, 5, 89-101.

86. Colombo, L. Il Turismo Responsabile; Xenia: Milano, Italy, 2005. (In Italian).

87. Frey, N.; George, R. Responsible tourism management. Tour. Manag. 2010, 31, 621-628.

88. Goodwin, H.; Francis, J. Ethical and responsible tourism. J. Vacat. Mark. 2003, 9, 271-284.

89. Pennington-Gray, L.; Reisinger, Y.; Kim, J.E.; Thapa, B. Do U.S. tour operators' brochures educate the tourist on culturally responsible behaviours? J. Vacat. Mark. 2005, 11, 265-284.

90. Sambri, C.; Pegan, G. La domanda di turismo responsabile. Mercat. Compet. 2008, 1, 65-92. (In Italian).

91. Dolnicar, S.; Matus, K. Are Green Tourists a Managerially Useful Target Segment? J. Hosp. Leis. Mark. 2008, 17, 314-334.

92. Hong, S.; Kim, S.; Kim, J. Implications of potential green tourism development. Ann. Tour. Res. 2003, 30, 323-341.

93. Holtz, C.; Edwards, S. Linking Biodiversity and Tourism Policy. In Ecotourism, Policy and Planning; Fennel, D.A., Dowling, R.K., Eds.; CAB International: Oxon, UK, 2003; pp. 39-54.

94. Fennel, D.A. A content analysis of ecotourism definitions. Curr. Issues Tour. 2001, 4, 403-421.

95. Luo Y.; Deng, J. The new Environmental Paradigm and Nature-Based Tourism Motivation. J. Travel Res. 2008, 46, 392-402.

96. Perkins, H.E.; Brown, P.R. Environmental Values and the So-Called True Ecotourist. J. Travel Res. 2012, 51, 793-803.

97. Blamey, R. Ecotourism: The search for an operational definition. J. Sustain. Tour. 1997, 5, 109-130.

98. Blamey, R. Principles of ecotourism. In The Encyclopedia of Ecotourism; Weaver, D.B., Ed.; CABI: Wallingford, UK, 2001; 5-22.

99. Goodwin, H. In Pursuit of Ecotoruism. Biodivers. Conserv. 1996, 5, 277-291.

100. UNWTO. The Italian Ecotourism Market; Unwto: Madrid, Spain, 2002.

101. Laarman, J.; Durst, P. Nature Travel and Tropical Forests (FREI Working Paper Series); Southeastern Center for Forest Economics Research: Raleigh, NC, USA, 1987.

102. Hunter, C. Sustainable Tourism and the Touristic Ecological Footprint. Environ. Dev. Sustain. 2002, 4, 7-20.

103. Diamantis, D. The characteristics of UK's ecotourists. Tour. Recreat. Res. 1999, 24, 99-102. 
104. Palacio, V.; McCool, S. Identifying ecotourists in Belize through benefit segmentation. J. Sustain. Tour. 1997, 5, 234-243.

105. Fennel, D.A. The Canadian ecotourist in Costa Rica. Int. J. Sustain. Dev. 2002, 5, 282-299.

106. Weaver, D.B. A Broad Context Model of Destination Development Scenarios. Tour. Manag. 2000, 21, 217-224.

107. Crompton, J.L. Motivations for pleasure vacation. Ann. Tour. Res. 1979, 6, 408-424.

108. Dann, G.M.S. Anomie, ego-enhancement and tourism. Ann. Tour. Res. 1977, 4, 184-194.

109. McIntosh, R.W.; Goeldner, C.R. Tourism. Principles, Practices, Philosophies; Wiley: New York, NY, USA, 1990.

110. Moscardo, G.; Morrison, A.M.; Pearce, P.L.; Lang, C.T.; O’Leary, J. Understanding vacation destination choice through travel motivation and activities. J. Vacat. Mark. 1996, 2, 109-122.

111. Plog, S.C. Why destination areas rise and fall in popularity. Cornell Hotel Rest. Q. 1974, 14, 55-58.

112. Plog, S.C. Why destination areas rise and fall in popularity. An Update of a Cornell Quarterly Classic. Cornell Hotel Rest. Admin. Quart. 2001, 42, 13-24.

113. Ozdemir, B.; Aksu, A.; Ehtiyar, R.; Çizel, B.; Çizel, R.B.; İçigen, E.T. Relationships Among Tourist Profile, Satisfaction and Destination Loyalty. J. Hosp. Mark. Manag. 2012, 21, 506-540.

114. Schmidhauser, H. Tourist needs and motivations. In The Tourism Marketing and Management Handbook; Witt, S., Moutinho, L., Eds.; Prentice Hall: London, UK, 1989; pp. 569-572.

115. Schmoll, G.A. Tourism Promotion; Tourism International Press: London, UK, 1977.

116. Vukic, M.; Kuzmanovic, M; Stankovic, M.K. Understanding the Heterogeneity of Generation Y's Preferences for Travelling: A Conjoint Analysis Approach. Int. J. Tour. Adm. Res. 2014, doi:10.1002/jtr.2015.

117. Huntley, R. The World According to Y; Allen and Unwin: Crows Nest, Australia, 2006.

118. Benckendorff, P.; Moscardo, G.; Murphy, L. Environmental Attitudes of Generation Y Students. J. Teach. Travel. Tour. 2012, 12, 44-69.

119. Loker-Murphy, L.; Pearce, P.L. Young budget travelers: Backpackers in Australia. Ann. Tour. Res. 1995, 22, 819-843.

120. Cohen, E. Backpacking: Diversity and Change. J. Tour. Cult. Ch. 2003, 1, 95-110.

121. Larsen, S.; Øgaard, T.; Brun, W. Backpackers and Mainstreamers. Ann. Tour. Res. 2001, 38, 690-707.

122. Elsrud, T. Risk creation in traveling: Backpacker adventure narration. Ann. Tour. Res. 2001, 28, 597-617.

123. Hampton, M.P. Backpacker tourism and economic development. Ann. Tour. Res. 1998, 25, 639-660.

124. Jennings, G.; Cater, C.; Lee, Y.-S.; Ollenburg, C.; Ayling, A. Generation Y: Perspectives of quality in youth adventure travel experiences in an Australian backpacker context. In Tourism and Generation Y; Benckendorff, P.J., Moscardo, G., Pendergast, D., Eds.; CABI: Oxfordshire, UK, 2010; pp. 58-72.

125. O'Reilly, C.C. From drifter to gap year tourist. Ann. Tour. Res. 2006, 33, 998-1017.

126. Mohsin, A.; Ryan, C. Backpakers in the Northern territory of Australia. Int. J. Tour. Res. 2003, 5 , 113-131.

127. Maoz, D. Backpackers' motivations the role of culture and nationality. Ann. Tour. Res. 2007, 34, 122-140. 
128. Noy, C.; Cohen, E. (Eds.) Israeli Backpackers; State University of New York Press: Albany, NY, USA, 2005.

129. Ooi N.; Laing, J.H. Backpacker tourism: Sustainable and purposeful? J. Sustain. Tour. 2010, 18, 191-206.

130. Hannam, K.; Ateljevic, I. Backpacker Tourism: Concepts and Profiles; Channel View Pubblications: Clevedon, UK, 2007.

131. Uriely, N.; Yonay, Y.; Simchai, D. Backpacking experiences. Ann. Tour. Res. 2002, 29, 520-538.

132. Cohen, S.A. Lifestyle travellers. Ann. Tour. Res. 2011, 38, 1535-1555.

133. Chisnall, P.M. Marketing Research, 3rd ed.; McGraw-Hill: London, UK, 1986.

(C) 2015 by the authors; licensee MDPI, Basel, Switzerland. This article is an open access article distributed under the terms and conditions of the Creative Commons Attribution license (http://creativecommons.org/licenses/by/4.0/). 